\title{
Hubungan Asfiksia Neonatorum dengan Gangguan Fungsi Ginjal pada Bayi Baru Lahir
}

\author{
Adrian Umboh
}

\begin{abstract}
Asfiksia neonatorum merupakan problem kesehatan pada bayi baru lahir yang dapat menyebabkan gagal ginjal akut jika tidak ditangani dengan baik.

Tujuan: untuk mengetahui hubungan antara derajat asfiksia neonatorum dengan derajat gangguan fungsi ginjal

Metoda: penelitian analitik observasional pada bayi baru lahir di bangsal Neonatologi Bagian IKA/RSUP Manado antara bulan Agustus 1997-Februari 1998 yang memenuhi kriteria dilakukan pengukuran kadar ureum dan kreatinin serum serta penentuan laju filtrasi glomerulus (LFG). Data dianalisis dengan uji Anova dan Chi-Square.

Hasil: di antara 129 bayi baru lahir yang memenuhi kriteria terdiri dari 49 bayi sehat, 50 asfiksia ringan-sedang, dan 30 asfiksia berat. Terdapat perbedaan bermakna kadar serum ureum dan kreatinin serta LFG antara kelompok bayi sehat dengan asfiksia berat dan antara kelompok asfiksia ringan-sedang dengan asfiksia berat $(p<0,01)$. Lima dari 30 kasus asfiksia berat mengalami gagal ginjal akut dan terdapat hubungan bermakna antara derajat asfiksia dengan derajat gangguan fungsi ginjal $(p<0,01)$.

Kesimpulan: terdapat perbedaan antara kadar ureum dan kreatinin serum serta LFG antara bayi asfiksia berat dengan bayi sehat dan asfiksia ringan-sedang. Terdapat pula hubungan antara derajat asfiksia dengan derajat gangguan fungsi ginjal.
\end{abstract}

Kata kunci: bayi baru lahir - asfiksia - gangguan fungsi ginjal

17

alam dua dekade terakhir ini teknik monitor bayi ante dan intra partum sudah berkembang pesat, namun risiko asfiksia pada bayi baru lahir tetap menjadi masalah. ${ }^{1,2}$ Asfiksia neonatorum merupakan salah satu problem kesehatan pada bayi baru lahir yang dapat menyebabkan hipoksemia, hiperkapnia dan asidosis, yang jika tidak ditangani dengan baik dapat menyebabkan gagal ginjal akut. ${ }^{3-9}$

Di antara ke-empat penyebab utama morbiditas bayi yang dirawat di Subbagian Neonatologi RSCM/ FKUI Jakarta, asfiksia neonatorum menempati urutan

\footnotetext{
Alamat Korespondensi:

Dr. Adrian Umboh, Sp.A.

Kepala Subbagian Nefrologi, Bagian Ilmu Kesehatan Anak, FKUNSRAT/RSUP Manado. Jl. Raya Tanawangko. Manado 95263.

Telepon: 0431-821652. Fax.: 0431-859091.

Makalah telah dibawakan di KONIKA XI, Jakarta 1999
}

kedua pada kelompok bayi dengan berat lahir cukup. ${ }^{10}$ Kematian akibat asfiksia neonatorum 17\% dari seluruh bayi dengan asfiksia berat yang dirawat di Subbagian Neonatologi RSUD Dr. Sutomo Surabaya pada tahun 1993. ${ }^{11}$

Gejala gangguan fungsi ginjal pada neonatus sangat tidak khas dan sering merupakan bagian dari disfungsi multiorgan seperti pada sindrom gawat nafas neonatorum yang berat. ${ }^{3-6,10}$ Stapleton $^{12}$ melaporkan bahwa 9 di antara 15 kasus gagal ginjal akut (GGA) pada neonatus yang dirawat di ICU mempunyai riwayat asfiksia perinatal dengan angka kematian akhir GGA berkisar antara 37-78\%.

Asfiksia neonatorum menyebabkan perfusi ginjal berkurang dan sering terjadi GGA setelah asfiksia berat. Hipoksia yang berlangsung lama akibat asfiksia berat akan menyebabkan iskemia ginjal sehingga dapat berlanjut menjadi GGA intrinsik. ${ }^{12-15}$ Carlowicz dan Adelman ${ }^{7}$ pada penelitian prospektif terhadap 33 bayi 
cukup bulan dengan asfiksia berat, mendapatkan $61 \%$ mengalami GGA sedangkan pada 33 bayi dengan asfiksia sedang tidak ditemukan GGA.

Tujuan penelitian ini untuk mengetahui hubungan antara derajat asfiksia neonatorum dengan beratnya gangguan fungsi ginjal.

\section{Hasil Penelitian}

Selama periode 1 Agustus 1997 sampai dengan 28 Februari 1998 telah diteliti 129 bayi yang memenuhi kriteria inklusi, terdiri dari 49 bayi normal, 50 bayi asfiksia ringan-sedang dan 30 bayi asfiksia berat. Karakteristik bayi tersebut dapat dilihat pada Tabel 1 .

Tabel 1. Rerata distribusi berat badan dan panjang badan, ureum dan kreatinin serum serta LFG menurut derajat asfiksia

\begin{tabular}{|c|c|c|c|c|}
\hline Parameter & $\begin{array}{l}\text { Sehat } \\
(\mathrm{n}=49)\end{array}$ & $\begin{array}{c}\text { Asfiksia } \\
\text { Ringan-sedang } \\
(\mathrm{n}=50)\end{array}$ & $\begin{array}{l}\text { Asfiksia berat } \\
\qquad(\mathrm{n}=30)\end{array}$ & Keterangan \\
\hline Berat lahir (g) & $3.206 \pm 322,9$ & $3.272,6 \pm 389,8$ & $3.249 \pm 418,9$ & $\mathrm{p}=0,6653$ \\
\hline Panjang lahir $(\mathrm{cm})$ & $48,1 \pm 1,5$ & $48,2 \pm 1,6$ & $48,2 \pm 1,5$ & $\mathrm{p}=0,5670$ \\
\hline Ureum serum (mg/dl) & $28,8 \pm 6,2$ & $31,0 \pm 7,9$ & $41,3 \pm 5,1$ & $\mathrm{p}<0,01$ \\
\hline Kreatinin serum $(\mathrm{mg} / \mathrm{dl})$ & $0,8 \pm 0,2$ & $0,9 \pm 0,2$ & $1,2 \pm 0,4$ & $\mathrm{p}<0.01$ \\
\hline LFG $\left(\mathrm{ml} / \mathrm{menit} / 1,73 \mathrm{~m}^{2}\right)$ & $30,8 \pm 7,9$ & $28,9 \pm 6,9$ & $22,2 \pm 6,4$ & $\mathrm{p}<0,01$ \\
\hline
\end{tabular}

\section{Bahan dan Cara}

Penelitian analitik observasional ini dilakukan di bangsal Neonatologi Bagian Ilmu Kesehatan Anak RSUP Manado sejak bulan Agustus 1997 sampai dengan Februari 1998. Subyek penelitian adalah bayi baru lahir di RSUP Manado dengan kehamilan cukup bulan, berat lahir sesuai masa kehamilan, tanpa kelainan kongenital, dan orang tua bersedia mengisi formulir persetujuan. Derajat asfiksia ditentukan dengan nilai Apgar sebagai berikut: nilai Apgar 7-10 (normal), nilai Apgar 4-6 (asfiksia sedang) dan nilai Apgar 0-3 (asfiksia berat). Pada setiap pasien dilakukan pengukuran berat badan, panjang badan, kadar ureum dan kreatinin serum serta penilaian fungsi ginjal.

Penilaian fungsi ginjal didasarkan pada kemampuan ekskresi ginjal yang dinyatakan sebagai laju filtrasi glomerolus dan fungsi ekskresi ureum dan kreatinin. Fungsi ginjal normal bila LFG $>75 \%$, gangguan fungsi ringan (azotemia prerenal) bila LFG 50-75\%, dan gangguan fungsi berat bila LFG $<50 \%$. LFG dihitung dengan rumus:

$$
\mathrm{LFG}=\frac{0,5 \times \text { panjang badan }(\mathrm{cm})}{\text { serum kreatinin }(\mathrm{mg} / \mathrm{dl})}
$$

Data dianalisis dengan uji Anova dan Chi-square dengan tingkat kemaknaan $\mathrm{p}<0,05$.
Dari Tabel 1 didapatkan distribusi berat lahir dan panjang lahir ke-tiga kelompok tidak berbeda. Sementara itu setelah dilakukan pengujian dengan LSD (beda nyata terkecil) diperoleh hasil bahwa: terdapat perbedaan bermakna kadar serum ureum dan kreatinin serta LFG antara kelompok bayi sehat dengan asfiksia berat dan antara kelompok asfiksia ringan-sedang dengan asfiksia berat $(\mathrm{p}<0,01)$, namun tidak terdapat perbedaan bermakna kadar serum ureum dan kreatinin antara kelompok bayi sehat dengan asfiksia ringansedang.

Di antara 49 bayi tanpa asfiksia hanya 2 kasus $(4,1 \%)$ yang mengalami gangguan fungsi ginjal ringan (azotemia prerenal), sedangkan dari 50 bayi dengan asfiksia ringan-sedang didapatkan 9 kasus (18\%) dengan gangguan fungsi ginjal ringan. Sedangkan dari 30 kasus asfiksia berat didapatkan 12 kasus (40,5\%) mempunyai fungsi ginjal normal, 13 kasus $(43,3 \%)$ dengan gangguan fungsi ginjal ringan dan 5 kasus (16,7\%) dengan GGA.(Tabel 2)

Dari perhitungan statistik terdapat hubungan yang bermakna antara beratnya asfiksia dengan beratnya gangguan fungsi ginjal.

\section{Diskusi}

Fungsi utama ginjal adalah untuk membersihkan plasma dari bahan yang tidak diperlukan oleh tubuh. 
Sari Pediatri, Vol. 4, No. 2, September 2002

Tabel 2. Hubungan asfiksia neonatorum dengan derajat gangguan fungsi ginjal

\begin{tabular}{lcccccccc}
\hline Fungsi ginjal & \multicolumn{2}{c}{ Sehat } & \multicolumn{2}{c}{ Asfiksia ringan-sedang } & \multicolumn{2}{c}{ Asfiksia berat } & \multicolumn{2}{c}{ Jumlah } \\
\cline { 2 - 9 } & $\mathrm{n}$ & $\%$ & $\mathrm{n}$ & $\%$ & $\mathrm{n}$ & $\%$ & $\mathrm{n}$ & $\%$ \\
\hline Normal & 47 & 47,00 & 41 & 41,00 & 12 & 12,00 & 100 & 100 \\
Azotemia prerenal & 2 & 8,33 & 9 & 37,50 & 13 & 54,17 & 24 & 100 \\
GGA & 0 & 0,00 & 0 & 0,00 & 5 & 100,00 & 5 & 100 \\
\hline \multicolumn{2}{c}{39,643} & $\mathrm{df}=4$ & \multicolumn{2}{c}{$\mathrm{p}=0,0000000513$}
\end{tabular}

Kreatinin dan ureum merupakan dua bahan utama yang dalam keadaan normal diekskresi melalui ginjal. ${ }^{16,17}$ Asfiksia neonatorum akan menyebabkan hipoksia dan hipoksemia yang pada akhirnya akan mengganggu perfusi organ vital terutama ginjal dan otak. ${ }^{1}$ Bila terjadi gangguan pada nefron yang diakibatkan oleh hipoperfusi atau hipoksia, maka klirens kedua bahan tersebut akan menurun dan kadarnya dalam darah akan meningkat seiring dengan penurunan laju filtrasi glomerulus. ${ }^{18}$ Pada penelitian ini didapatkan rerata kadar ureum serum kelompok bayi normal $28,8 \mathrm{mg} / \mathrm{dl}$, asfiksia ringan sedang 31,0 $\mathrm{mg} / \mathrm{dl}$ dan asfiksia berat $41,3 \mathrm{mg} / \mathrm{dl}$. Rerata kadar ureum serum ketiga kelompok berbeda secara bermakna $(p<0,001)$, hal ini menggambarkan terdapat pengaruh asfiksia terhadap peningkatan kadar ureum. Bila dibandingkan dengan penelitian Anand $\mathrm{dkk}^{14}$ hasilnya hampir sama yaitu kadar ureum pada bayi asfiksia berat $>40 \mathrm{mg} / \mathrm{dl}$.

Pada kelompok asfiksia berat terjadi peningkatan bermakna kadar kreatinin serum yaitu $1,2 \pm 0,4 \mathrm{mg} / \mathrm{dl}$, dibandingkan dengan bayi asfiksia ringan sedang $0,9 \pm 0,2 \mathrm{mg} / \mathrm{dl}$ dan pada kelompok bayi normal $0,8 \pm 0,2 \mathrm{mg} / \mathrm{dl}$. Hasil pengujian statistik memperlihatkan adanya hubungan sangat bermakna antara beratnya asfiksia dengan peningkatan kadar kreatinin $(\mathrm{p}<0,01)$. Dari 30 kasus asfiksia berat didapatkan 5 kasus dengan nilai LFG $<50 \%$ dan kadar kreatinin $>1,6$ $\mathrm{mg} / \mathrm{dl}$. Hal yang hampir sama dilaporkan oleh Anand $\mathrm{dkk}^{14}$ bahwa 14 kasus asfiksia berat dengan GGA nilai kreatinin $1,8 \mathrm{mg} / \mathrm{dl}$.

Gagal ginjal akut pada penelitian ini didapatkan 5 kasus (3,8\% dari semua kasus) atau $16,7 \%$ dari kasus asfiksia berat. Carlowicz dan Adelman ${ }^{7}$ melaporkan 20 dari 33 bayi asfiksia berat yang dirawat di ICU mengalami GGA. Perbedaan ini mungkin disebabkan pada penelitian Carlowicz bayi menderita asfiksia yang telah berlangsung lebih lama dan lebih berat; sedangkan pada kelompok asfiksia ringan-sedang didapatkan hasil yang sama yaitu tidak ada yang mengalami GGA. ${ }^{7}$

Rerata panjang badan kelompok asfiksia berat $48,2 \pm 1,5 \mathrm{~cm}$ (Tabel 1) secara statistik tidak berbeda bermakna dengan kelompok bayi normal dan bayi dengan asfiksia ringan- sedang. Mengingat panjang badan bayi relatif tetap maka nilai LFG hanya dipengaruhi oleh perubahan kadar kreatinin. Nilai normal LFG pada penelitian ini adalah $30,8 \pm 7,9 \mathrm{ml} /$ menit $/ 1,73 \mathrm{~m} .{ }^{2}$ Gagal ginjal akut terjadi bila LFG $<50 \%$ nilai normal, yang pada penelitian ini didapatkan batas GGA adalah $\mathrm{LFG}<15,4 \mathrm{ml} /$ menit $/ 1,73 \mathrm{~m}^{2}$ dengan kreatinin $>1,6 \mathrm{mg} / \mathrm{dl}$. Ke lima pasien yang mengalami GGA semuanya termasuk pada kelompok asfiksia berat. Hasil ini hampir sama dengan hasil penelitian oleh Mawardi ${ }^{19}$ yaitu GGA ditentukan dengan LFG $<50 \%$ nilai normal adalah $\mathrm{LFG}<14,5 \mathrm{ml} /$ menit $/ 1,73$ $\mathrm{m}^{2}$ dan kreatinin $>1,68 \mathrm{mg} / \mathrm{dl}$.

Secara fisiologis suplai darah ke daerah juksta medular lebih banyak dibandingkan korteks, padahal volume korteks 3 kali lebih besar dibandingkan medula dan secara mikroskopis membran basal glomerolus bayi tipis dan belum berkembang sempurna. ${ }^{13}$ Kondisi yang tidak menguntungkan tersebut menyebabkan fungsi ginjal pada bayi lebih mudah terganggu terutama pada keadaan stres yang dapat mempengaruhi proses metabolisme dan homeostasis. ${ }^{20}$ Gangguan fungsi ginjal pada tahap dini bersifat ringan dengan gejala azotemia prerenal yaitu kenaikan kadar kreatinin dan ureum serum akibat hipoperfusi di daerah korteks. Tahap selanjutnya gangguan bersifat sedang yang disebut GGA prerenal yang disebabkan hipoperfusi di daerah medula. Jika keadaan tersebut berlangsung lama maka akan terjadi gangguan fungsi ginjal berat yaitu terjadinya perubahan struktur ginjal berupa nekrosis di tubulus atau korteks yang disebut GGA intrinsik. ${ }^{15}$ Pada penelitian ini hanya dapat dilakukan pemeriksaan kadar ureum dan kreatinin serum, sedangkan pemeriksaan urin tidak dapat dilakukan sehingga belum bisa dideteksi kemungkinan terjadinya GGA intrinsik. 


\section{Kesimpulan}

Dari hasil penelitian ini dapat disimpulkan bahwa terdapat perbedaan antara kadar ureum dan kreatinin serum bayi asfiksia berat dengan bayi sehat dan bayi asfiksia ringan-sedang, makin berat asfiksia yang terjadi makin tinggi nilai ureum dan kreatinin. Penurunan LFG pada bayi asfiksia berat juga berbeda bermakna dengan kelompok asfiksia ringan-sedang dan bayi normal. Nilai LFG normal pada penelitian ini adalah $30,8 \pm 7,9 \mathrm{ml} / \mathrm{menit} / 1,73 \mathrm{~m}^{2}$ sedangkan nilai LFG 50\% dari nilai normal adalah $15,4 \mathrm{ml} /$ menit $/ 1,73 \mathrm{~m}^{2}$. Terdapat pula hubungan antara derajat asfiksia dengan gangguan fungsi ginjal.

\section{Daftar Pustaka}

1. Sabrine N, Singh J, Sinha SK. Medical management of birth asphyxia. Indian Pediatr 1999; 36:369-76.

2. Pramanik A. Respiratory distress syndrome. eMedicine J 2001; 2(7). Diakses dari http://www.emedicine.com/ped/ topic149.htm.

3. Marenstein GB. Predicting neonatal morbidity after perinaltal asphyxia: A scoring system. Am J Obstet Gynecol 1990; 162:174-82.

4. Polito C, Papale MR, La Manna A. Long term prognosis of acute renal failure in the full term neonate. Clin Pediatr (Phila) 1998; 37:381-5.

5. Mohan PV, Pai PM. Renal insult in asphyxia neonatorum. Indian Pediatr 2000; 37:1102-6.

6. Guignard YP, Torrado A, Mazouni SM, Gauntier E. Renal function in respiratory distress syndrome. J Pediatr 1976; 88:845-5.

7. Carlowicz GM, Adelman RD. Nonoliguric and oliguric renal failure in asphyxiated term neonate. Pediatr Nephrol 1995; 9:718-22.

8. Prakash J, Kumar H, Kumar NS, Bhatia BD. Neonatal acute renal failure. A hospital based study. Indian J Nephrol 2000; 10(4). Diakses dari http//www.ijnephrol.com.

9. Chair I. Resusitasi pada bayi baru lahir. Dalam: Marwoto BW, Widodo E, Kamarul I. penyunting. Penanganan gangguan nafas pada neonatus. Forum Ilmiah Tahunan V RSAB Harapan Kita. Jakarta 1992:17-25.

10. Monintja HE. Masalah umum sindroma gawat nafas pada neonatus. Dalam: Monintja HE, Aminullah A, Boedjang RF, Amir I. penyunting. Sindroma gawat nafas pada neonatus. Naskah Lengkap PKB IKA FKUI XXIII; Jakarta. Balai Penerbit FKUI 1991:1-13.

11. Indarso F. Gawat nafas pada bayi baru lahir. Pelatihan penanganan penderita gawat darurat bagi tenaga medis dan paramedis se-wilayah Indonesia Timur. 1995:1-20.

12. Stapleton FB, Jones DP, Green RS. Acute renal failure in neonates: incidence, etiology and outcome. Pediatr Nephrol 1987; 1:314-20.

13. Jain R. Acute renal failure in the neonate. Pediatr Clin N Am 1977; 24:605-17.

14. Anand SK, Northway JD, Crussi FG. Acute renal failure in newborn infants. J Pediatr 1978; 92:985-8.

15. Brezis M, Rosen S, Epstein FH. Acute renal failure. Dalam: Brenner BM, Rector FC. penyunting. The Kidney, edisi ke-4. Philadelphia: WB Saunders Co, 1991:993-1039.

16. Alatas H. Penilaian fungsi ginjal pada neonatus. Dalam: Marnoto M, Pusponegoro TS, Monintja HE. penyunting. Masalah ginjal dan saluran kemih di Bidang Perinatologi. Perinatologi 2000. Jakarta: Balai Penerbit FKUI, 1994:7-14.

17. Rifai FB. Embriologi dan fisiologi saluran kemih neonatus. Dalam: Marnoto M, Pusponegoro TS, Monintja HE. penyunting. Masalah ginjal dan saluran kemih di Bidang Perinatologi. Perinatologi 2000. Jakarta: Balai Penerbit FKUI, 1994:1-6.

18. Willis F, Summers J, Minutillo C, Hewitt I. Indices of renal tubular function in perinatal asphyxia. Arch Dis Child Fetal Neonatal Ed 1997; 77:57-60.

19. Mawardi H. Gangguan fungsi ginjal pada hipoksia neonatorum. MDK 1992; 11:17-19.

20. Airede A, Bello M, Weerasinghe HD. Acute renal failure in the newborn: Incidence and outcome. J Pediatr Child Health 1997; 33:246-9. 